\title{
Species composition, richness and diversity of fish assemblages in different habitats of a pampean lake (Argentina) ${ }^{1}$
}

\author{
M.J. Barla ${ }^{2}$
}

Keywords : fish assemblages, species richness, diversity, Pampean lake.

This study was based on the hypothesis that different associations can be described as subsystems that interchange production by means or their mobile elements : namely the fish. The Chascomús Lake was sampled at 19 sites over two years. Different habitats based on the presence or absence of vegetation and substrate type were determined. The association of fish to the different environments displayed seasonality. Some species can be considered opportunists, others are limited by some variables and a third group moves according to intrinsic behaviour. Species richness in higher in coastal environments. Diversity shows gradients that indicate true boundaries, though it never reaches saturation levels.

Composition, richesse et diversité spécifique des communautés piscicoles dans différents biotopes d'un lac de la Pampa (Argentine)

Mots clés : communautés piscicoles, richesse spécifique, diversité, lac, Pampa argentine.

Cette étude avait pour objectif de rechercher et de décrire les différentes associations coexistant au sein du lac et pouvant être décrites comme des sous-systèmes qui échangent leurs productions par leurs éléments les plus mobiles : les poissons. 19 stations du lac Chascomús ont été échantillonnées pendant deux ans. Différents types d'habitats ont été déterminés en fonction des peuplements végétaux et de la nature du substrat. Les communautés de poissons des différents milieux varient selon la saison. Quelques espèces de poissons sont opportunistes, certaines sont limitées par des facteurs environnementaux et d'autres, enfïn, se deplacent en fonction des paramètres intrinsèques de leur comportement. La richesse en espèce est maximale dans les milieux littoraux. La diversité n'atteint jamais des niveaux de saturation des biotopes et elle présente des gradients qui indiquent la présence de véritables frontières au sein du milieu.

\section{Introduction}

Relationships between fish and continental habitats have been studied in lotic environments (Gorman \& Karr 1978, Moreau \& Legendre 1979, Savard \& Moreau 1981), in marshlands (Hernando Casal \& Giménez Muela 1980), in glacial lakes (Gascon \& Legget 1977) and in small lakes in northern Wisconsin (Tonn \& Magnuson 1982). In South America, some scarce biocenologic studies of fishes have been done : Lowe-MacConnell (1975) and Pérez (1984) in tropical Guayana River ; Pignalberi de Hassan \& Cordiviola de Yuan (1988) in the Parana river.

1. Scientific Contribution $N^{\circ} 459$ of the Instituto de Limnologia « Dr Raùl A. Ringuelet ".

2. Instituto de Limnologia « $D^{r}$ Raùl A. Ringuelet », c.c. 712 - (1900) La Plata, B.A. Argentina.
In Chascomús Lake, only Destéfanis \& Freyre (1972) and Ringuelet (1975) have given qualitative data on the fish community.

In the present paper the structure of the fish community in Chascomús Lake, which is considered representative of Pampean lakes, is analyzed. The study was based on the following hypothesis : different associations interpreted as subsystems that can interchange production by means of their more vagile faunistic elements can be found in Pampean lakes. The purpose of this paper is :

1. to differentiate associations or subsystems by means of fish composition, vegetation, and topography ;

2. to analyze fish species richness and diversity and their relationship with environmental factors. 


\section{Study area}

Pampean lakes are shallow, permanent bodies, lacking thermal and chemical stratification (third class lakes according to Hutchinson 1957). The shallowness and topography are adequate for deeply rooted vegetation (Ringuelet 1962).

Chascomús Lake (fig. 1) is located in northeastern Buenos Aires Province, Argentina ( $35^{\circ} 35^{\prime} \mathrm{S}$, $\left.58^{\circ} 00^{\prime} \mathrm{W}\right)$. It is connected to the north with Vitel Lake and to the south with Adela Lake. The surface area is $30.14 \mathrm{~km}^{2}$, the coast line is $28.12 \mathrm{~km}$ and its mean depth is $1.56 \mathrm{~m}$ (Dangavs 1976). Its salinity ranges from 0.5 to $5 \mathrm{~g} / 1$ and the ionic composition is sodium chloride bicarbonate (Ringuelet 1972). The water is scarcely transparent and presents high turbidity near the mouth of streams (Conzono \& Fernández Cirelli 1987).

\section{Material and methods}

19 sites were sampled in a preliminary study from July 1984 to March 1985 with different fishing gear : fyke net, trapnet and trawlnets (see characteristics in Nédélec 1975). From March 1985 to March 1986 eleven sites (fig. 1) were monthly sampled with a

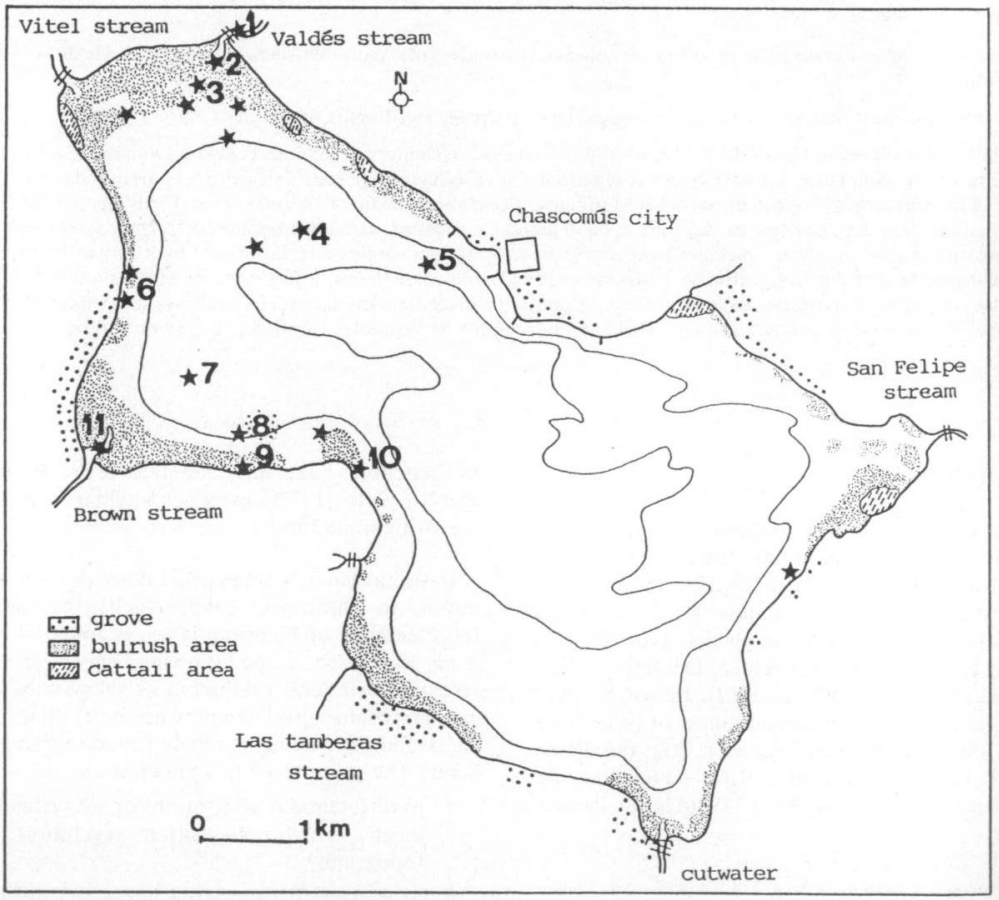

Fig. 1. Chascomús lake. The asterisks indicate the 19 sampling sites locations. The numbers indicate the 10 sites treated statistically. 
coastal trawlnet of $15 \mathrm{~m}$ of floatline, a funnel of $2.2 \mathrm{~m}$ and square mesh of $9.71 \mathrm{~mm}$. Simultaneously, the presence and abundance of vegetation, substrate type and depth were noted and conductivity, $\mathrm{pH}$, oxygen, temperature and turbidity were measured with a Horiba U7 multimeter. Transparency was measured with a Secchi disk.

Catches are expressed in number of specimens per unit of effort. This latter consists of each throw with the trawlnet and 24 hours with traps. Samples obtained by means of different arts have not been compared. The specimens were identified, counted and weighed to within $0.5 \mathrm{~g}$.

A cluster analysis of sampling sites with the Jaccard association coefficient (see Hubalek 1982) was made using vegetation and substrate characteristics. Several Principal Component Analyses (PCA), (Hotelling 1933 in Legendre \& Legendre 1979) were done for detecting patterns in sampling sites according to the presence and abundance of fish species. One PCA used as an estimate of the limnological features and the abundance of fish species was derived from a correlation matrix. Several other PCA used only the fish species data derived from covariance matrixes in different seasons. The average of each species abundance in each sampling site and season was noted in the matrixes. Species failing to occur in some seasons were not used. The richness or density of species was taken as the number of species occurring at each sampling site (Pianka 1982) and the specific diversity was calculated from the Shannon-Weaver formula, maximum diversity and minimum diversity (Margalef 1974). Isolines joining sites of equal diversity were plotted with a scalemeter taking into account the best represented seasons.

\section{Results}

Cluster analysis of sampling sites using topography, substrate and presence and abundance of macrophytes (Table I, fig. 2) showed three groups related with low degree of similarity : the five of $f$ shore sites $(3,8,5,7,4)$, the five littoral sampling sites $(2,11,9,1,10)$ and one littoral sampling site with caliche substrate and the sole record of Schoenoplectus californicus (6). The of $\mathrm{f}$-shore sites are grouped in 4 (with Potamogeton striatus) and 3, 8, 5 and 7 ; sites 3 and 8 with bulrush, 5 and 7 in open waters. The littoral sites are grouped in 10 and,

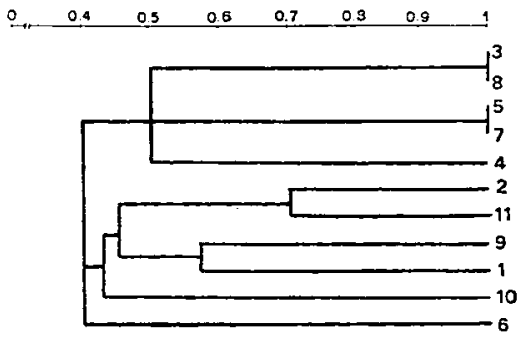

Fig. 2. Similitude between sampling sites based on macrophytes, sediment types and topography.

2 and 11,9 and 1 . The disappearance of area with $\boldsymbol{P}$. striatus was observed after a high water level period.

Table II shows the occurrence of fish species in sampling sites during two years in winter, spring and summer.

The PCA of the sampling sites using the catch abundance average through the year shows that the first two components represent $93.87 \%$ of total variance (first axis : $64.14 \%$; second axis : $29.73 \%$ ). The first axis discriminates 9,3 and the rest $(f i g .3 \mathrm{~A}$ ). The second axis discriminates 11 .

In the PCA for winter catches the first two components represent $84.63 \%$ of total variance (Table III). The first and second component discriminate between 1 and the rest as well as three open water sites (3, 7 and 8), 6 and 5 (fig. 3 B). Sites 8 and 7 appear grouped as they are in real space.

In the PCA for spring catches, the first two components represent $98.48 \%$ of total variance (Table III). The first component $(96.07 \%$ ) discriminates site 10 from the other (fig. $3 \mathrm{C}$ ).

In the PCA for summer catches, the first two components represent the $96.13 \%$ of total variance (Table III). The first component discriminates two groups separated from sampling site 9 (fig. $3 \mathrm{D}$ ). The second component discriminates site 11 from the rest. 
Table I. Macrophytes, sediment types and topography. 1 : present : $O$ : absent.

\begin{tabular}{|c|c|c|c|c|c|c|c|c|c|c|c|}
\hline MACROPHYTES SAMPLING SITES & 1 & 2 & 3 & 4 & 3 & $t$ & 7 & $\mathbf{B}$ & 9 & 10 & 11 \\
\hline \multicolumn{12}{|l|}{ Schoenoplectus celitornicus } \\
\hline (Mever) Sojak (dense) & 0 & 1 & 0 & 0 & 0 & 0 & 0 & 0 & 0 & 1 & 1 \\
\hline Cecatophylium gemersum $L$. & 1 & 1 & 0 & 0 & 0 & 0 & 0 & 0 & 1 & 1 & 1 \\
\hline A20lia filiculoides Lam. & 1 & 3 & 0 & 0 & 0 & 0 & 0 & 0 & 0 & 0 & 0 \\
\hline Lemna minor L. & 1 & 1 & 0 & 0 & 0 & 0 & 0 & 0 & 0 & 0 & 1 \\
\hline Hydromystia ievials (willd.) & & & & & & & & & & & \\
\hline $\begin{array}{l}\text { Hunziker } \\
\text { Potamogeton pitiatus Ruiz ot }\end{array}$ & 0 & 1 & 0 & 0 & 0 & 0 & 0 & 0 & 0 & 0 & 0 \\
\hline 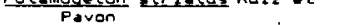 & 0 & 0 & 0 & : & 0 & 0 & 0 & 0 & 0 & 0 & 0 \\
\hline Miriogmylium guitense H. V. K. & 0 & 0 & 0 & 0 & 0 & 0 & 0 & 0 & 0 & 0 & 0 \\
\hline $\begin{array}{l}\text { Hydrocotyle so } \\
\text { Alternantners oniloxeroiges }\end{array}$ & 0 & 0 & 0 & 0 & 0 & 0 & 0 & 0 & 0 & 0 & 1 \\
\hline (Mart.) Griseo. & $\circ$ & 1 & 0 & 0 & 0 & 0 & 0 & 0 & 0 & 0 & o \\
\hline Rieciocarous natans $(\mathrm{L}$.$) Corda$ & 0 & 1 & 0 & 0 & 0 & 0 & 0 & 0 & 0 & 0 & 1 \\
\hline S. 5alitornicus isparse) & 1 & 1 & 1 & 0 & 0 & 1 & 1 & 0 & 1 & 1 & 1 \\
\hline Filamentous Chlorophytes & 0 & 0 & 0 & 0 & 0 & 0 & 0 & 0 & 0 & 1 & 0 \\
\hline mud bottam & 1 & 1 & 1 & 1 & 1 & 0 & 1 & 1 & 1 & 0 & 1 \\
\hline Coastal site & 1 & 0 & 0 & 0 & 0 & 1 & 0 & 0 & 1 & 1 & 0 \\
\hline
\end{tabular}

Table II. Fish species list and their occurence in sampling sites during two years.

$\mathrm{W}$ : present in winter sampling only ; $\mathrm{Sp}$ : present in spring only; $\mathrm{S}:$ present in summer only $; *$ : present in the three seasons.

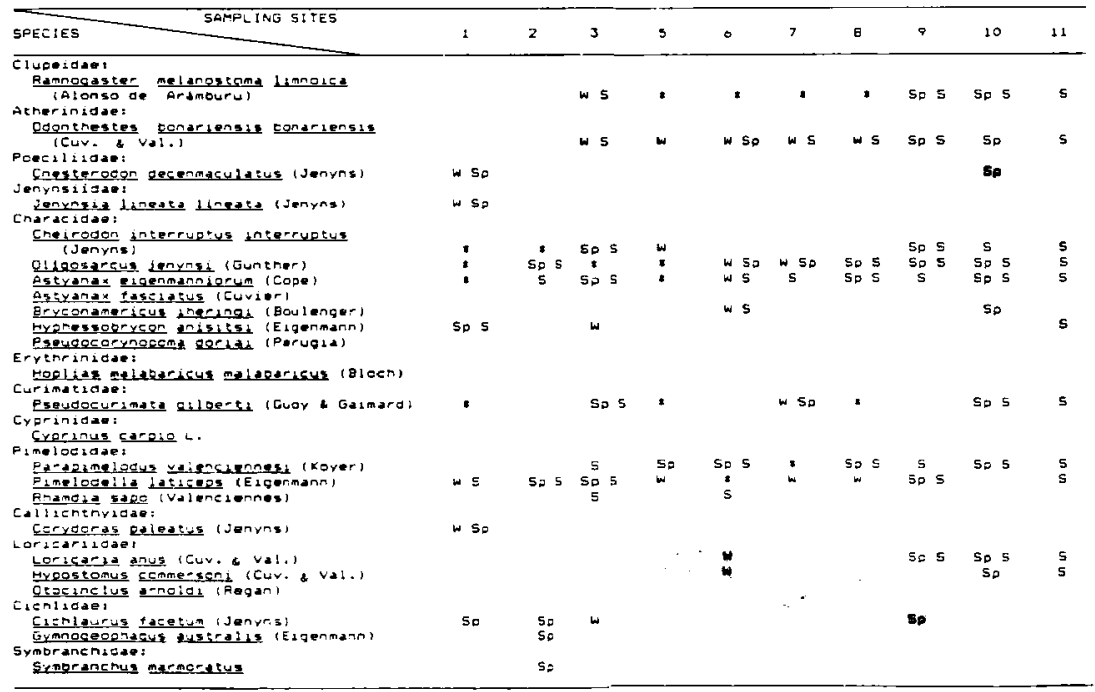


Table III. PCA of a winter, spring and summer sampling. Coordinates $\mathrm{I}$ and II and its character loadings.

\begin{tabular}{|c|c|c|c|c|}
\hline \multirow{4}{*}{ WINTER } & Ch. interruptus & 0.553 & Ch. interruptus & 0.713 \\
\hline & O. jenynsi & -0.253 & P. laticeps & 0.436 \\
\hline & P. taticeps & -0.644 & O. jenynsi & 0.243 \\
\hline & & & H. commersoni & 0.202 \\
\hline \multirow{5}{*}{ SPRING } & R. m. limnoica & 0.996 & O. jenynsi & 0.663 \\
\hline & & & P. laticeps & 0.627 \\
\hline & & & B. b. bonariensis & 0.294 \\
\hline & & & P. valenciennesi & -0.253 \\
\hline & \multicolumn{2}{|c|}{ COOR I $72 \%$} & \multicolumn{2}{|c|}{ COOR II $24.13 \%$} \\
\hline
\end{tabular}
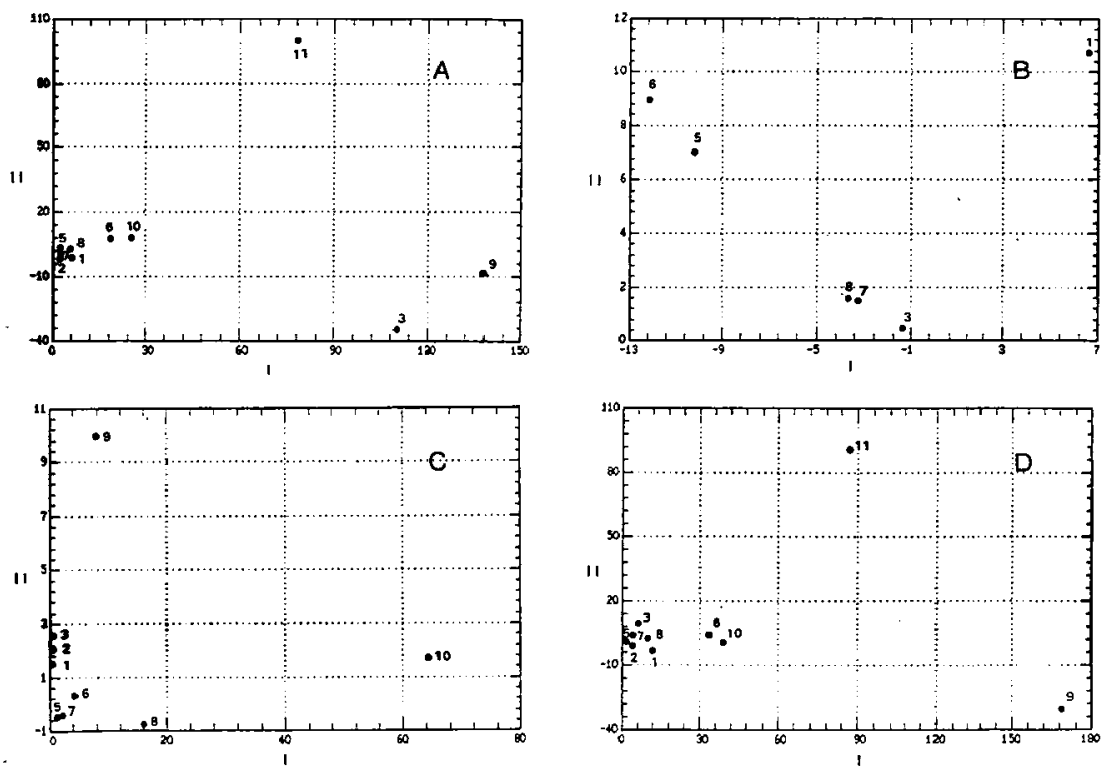

Fig. 3, PCA of sampling sites based on fish species abundance.

A : analysis of a year sampling ; B : analysis of winter sampling ; C : analysis of spring sampling ; D : analysis of summer sampling. 


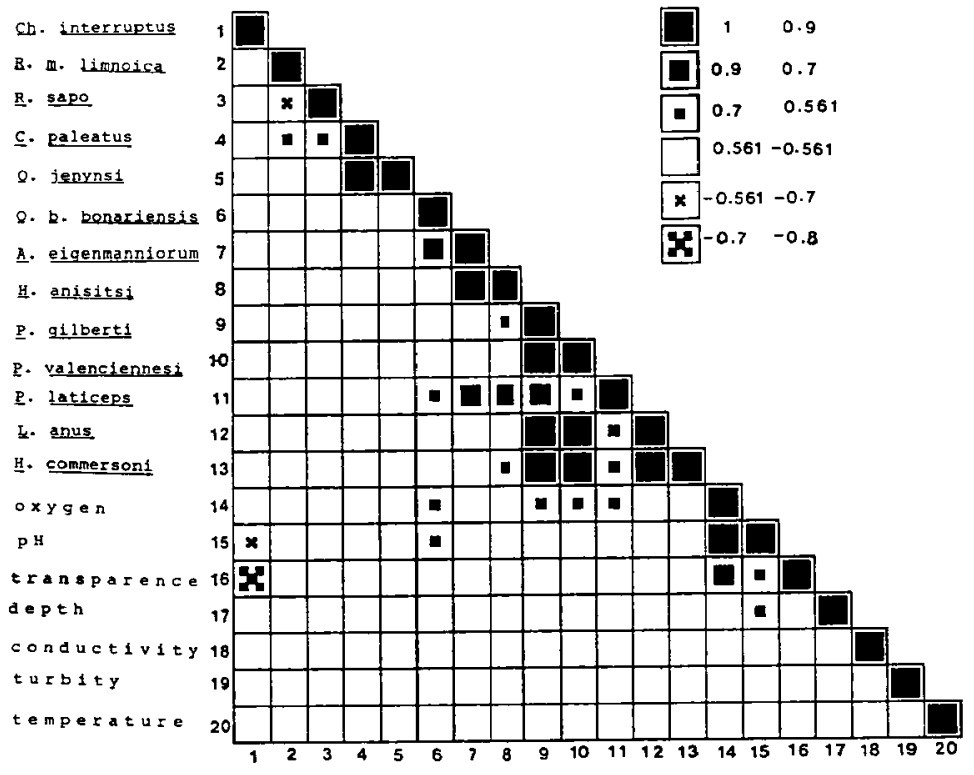

Fig. 4. A shaded correlation matrix of fish species and habitat factors.

A summer analysis using species abundance and limnological features was made due to the fact that the sampling in this season was more abundant that in the rest of the year. A matrix (fig. 4) shows with different symbols from 0.561 , significant to $1 \%$ for 18 liberty degrees (Snedecor and Cochran 1967) the correlation coefficients. Oxygen presents a high correlation with $\mathrm{pH}$ and transparence and with the species $O$. b. bonariensis, $P$. gilberti, $P$. valenciennesi and $P$. laticeps. $O$. b. bonariensis presents positive correlation with $\mathrm{pH}$ and $\mathrm{Ch}$. interruptus shows a negative correlation with $\mathrm{pH}$ and depth.

Fish relative abundance was calculated for all samples :

(For littoral sites)
Site 1:

Ch. interruptus (37.7\%)

A. eigenmanniorum $(29.2 \%)$

O. jenynsi $(14.6 \%)$

Site 11:

P. gilberti $(28.47 \%)$

$P$. valenciennesi $(27.05 \%$ )

$P$. laticeps (14.95\%)

A. eigenmanniorum $(14.23 \%)$

Site 6 :

O. jenynsi $(31.62 \%)$

R. m. limnoica $(24 \%)$

A. eigenmanniorum (13.49\%) 
Site 9 :
A. eigenmanniorum $(53.1 \%)$
P. laticeps $(18.11 \%)$

Site 10:
R. m. limnoica $(34.03 \%)$
A. eigenmanniorum $(24.24 \%)$
$O$. jenynsi $(13.3 \%)$
P. laticeps $(10.7 \%)$

(For off shore sites)

Site 2 :
O. jenynsi $(37.5 \%)$
R. m. limnoica $(18.75 \%)$
Ch. interruptus $(16.7 \%)$
P. laticeps $(12.5 \%)$
A. eigenmanniorum $(10.4 \%)$

Site 3 :

A. eigenmanniorum $(86,5 \%)$

Site 8 :
R. m. limnoica $(40.37 \%$ )
A. eigenmanniorum $(18.85 \%)$
$P$. valenciennesi $(16.15 \%)$

Site 5 :

R. m. limnoica $(33.33 \%)$

$O$. jenynsi $(29.63 \%)$

$P$. valenciennesi $(11.11 \%)$

Site 7 :
P. valenciennesi $(28 \%)$
$P$. laticeps $(21.2 \%)$
O. jenynsi $(15.25 \%)$
R. m. limnoica $(13.96 \%)$

Specific diversity according to the ShannonWeaver index, maximum and minimum diversity and species richness were calculated (Table IV). Diversity isolines in ten sampling sites in winter, spring and summer were drawn (fig. 5, 6, 7). During the winter, a greater diversity in the west coast diminishing to the east and increasing steply to site 1 through bulrushes was observed. In spring, diversity was in general lower ; the gradient at site 1 was inverted. In summer, diversity was higher in the west, at the sites 6 and 11 . Species density of total sampling (Table V), was higher in the west and was less variable with lower standard deviation at site 6. Density was higher in coastal sites than in offshore sites.

\section{Discussion and conclusions}

According to Margalef (1980) the organization of ecologic space by means of several species has analogies with PCA procedures used for analyzing a set of variables. The latter should represent different dimensions of ecologic space or ecologic niche space.

Fish species abundance PCA arranges sites according to fish composition ; the data of relative abundance complete the information.

Sites 9 and 11 are distinguished from the rest by means of the total catche PCA (fig. $3 \mathrm{~A}$ ) and the summer catche PCA (fig. 3 D). Site 9 is distinguished both by $A$. eigenmannionum presence and abundance ; however, this species can introduce great variations due to its frequent habitat displacements. Site 11 is discriminated by $P$. gilberti and $P$. valenciennesi. Fish species composition and abundance in the different environments vary seasonally. The abundant summer catches notably influence the analysis of total sampling. The carp C. carpio, a first record for the area (Barla \& Iriart 1987), was not considered in the analysis.

In winter, site 1 was differentiated by the occurence and abundance of $\mathrm{Ch}$. interruptus (fig. $3 \mathrm{~B}$ ). Turbulence, a factor present in this site, was not measured, but it was smaller at the mouth of the Brown stream site (11) than at the mouth of the Valdés stream (1). When separating western and southwestern sites from northern sites, species occurrence could discriminate wind direction, thus influencing seasonal displacements.

The spring PCA (fig $3 \mathrm{C}$ ) separates site 10 due to the abundance of $R$. m. limnoica, one of the three plankton-feeding species in the lake.

In the correlation analysis of species and limnological features of summer sampling (fig. 4) some alleged off-shore and plankton-feeding species (Ringuelet 1975 ) like $P$. valenciennesi and $R$. m. limnoica are good coastal indicators and are limited by oxygen and temperature. They are frequent at a sampling site such as 6 which is coastal, with caliche substrate, scarce vegetation and with a nearby small temporary stream of pluvial origin. $P$. valenciennesi is absent only in winter (Table II). In the same way, $P$. laticeps, allegedly frequent in vegetated environments (cf. Ringuelet 1975) also occurs off-shore ; its record is related with oxygen abundance. 
Table IV. Species diversity $(\mathbf{H})$, maximum species diversity (HMA), minimum species diversity (HMI) and species rickness (RI)

\begin{tabular}{|c|c|c|c|c|c|}
\hline SITE & DATE & $H$ & HMA & HMI & RI \\
\hline I & $\begin{array}{r}8 / 85 \\
10 / 85 \\
12 / 85 \\
1 / 86 \\
2 / 86\end{array}$ & $\begin{array}{l}2.18 \\
2.51 \\
0.81 \\
1.73 \\
2.18\end{array}$ & $\begin{array}{l}3 \\
3.17 \\
1 \\
2.32 \\
2.32\end{array}$ & $\begin{array}{l}1.73 \\
2.43 \\
0.81 \\
0.61 \\
1.26\end{array}$ & $\begin{array}{l} \\
9 \\
2 \\
5 \\
5\end{array}$ \\
\hline 2 & $\begin{array}{r}12 / 85 \\
1 / 86 \\
2 / 86\end{array}$ & $\begin{array}{l}1.37 \\
0.95 \\
2.36\end{array}$ & $\begin{array}{l}1.58 \\
1 \\
2.58\end{array}$ & $\begin{array}{l}1.37 \\
0.44 \\
0.99\end{array}$ & $\begin{array}{l}3 \\
2 \\
6\end{array}$ \\
\hline 3 & $\begin{array}{r}8 / 85 \\
8 / 85 \\
8 / 85 \\
12 / 85 \\
1 / 86 \\
2 / 86\end{array}$ & $\begin{array}{l}0.92 \\
1.26 \\
1.25 \\
2.13 \\
1.18 \\
1.44\end{array}$ & $\begin{array}{l}1.58 \\
1.58 \\
1.58 \\
2.32 \\
1.58 \\
2.58\end{array}$ & $\begin{array}{l}0.92 \\
0.73 \\
1.25 \\
2.13 \\
0.42 \\
0.71\end{array}$ & $\begin{array}{l}3 \\
3 \\
3 \\
5 \\
3 \\
6\end{array}$ \\
\hline 5 & $\begin{array}{r}6 / 85 \\
8 / 85 \\
+2 / 85 \\
1 / 86\end{array}$ & $\begin{array}{l}2.2 \\
0.97 \\
1.66 \\
1.69\end{array}$ & $\begin{array}{l}2 \cdot 58 \\
1 \\
2 \\
2\end{array}$ & $\begin{array}{l}0.65 \\
0.72 \\
1.66 \\
1.09\end{array}$ & $\begin{array}{l}6 \\
2 \\
4 \\
4\end{array}$ \\
\hline 6 & $\begin{array}{r}5 / 85 \\
6 / 95 \\
9 / 85 \\
12 / 85 \\
1 / 86 \\
2 / 86 \\
3 / 86\end{array}$ & $\begin{array}{l}2.24 \\
1.76 \\
2.6 \\
1.88 \\
1.82 \\
2.27 \\
2.29\end{array}$ & $\begin{array}{l}3 \\
2.58 \\
3 \\
2 \\
2 \\
3 \\
3\end{array}$ & $\begin{array}{l}0.6 \\
0.23 \\
1.31 \\
1.14 \\
1.29 \\
0.35 \\
0.4\end{array}$ & $\begin{array}{l}8 \\
6 \\
8 \\
9 \\
1 \\
8 \\
0\end{array}$ \\
\hline 7 & $\begin{array}{r}8 / 85 \\
\theta / 85 \\
12 / 85 \\
1 / 86 \\
2 / 86 \\
3 / 86\end{array}$ & $\begin{array}{l}1.41 \\
2.51 \\
1.5 \\
0.87 \\
1.58 \\
2.3\end{array}$ & $\begin{array}{l}1.58 \\
2.58 \\
1.58 \\
1.58 \\
1.58 \\
2.58\end{array}$ & $\begin{array}{l}1.06 \\
1.85 \\
1.5 \\
0.87 \\
0.77 \\
1.15\end{array}$ & $\begin{array}{l}3 \\
6 \\
3 \\
3 \\
3 \\
6\end{array}$ \\
\hline $\mathbf{\theta}$ & $\begin{array}{r}8 / 85 \\
8 / 85 \\
12 / 85 \\
1 / 86 \\
2 / 86 \\
3 / 86\end{array}$ & $\begin{array}{l}1.81 \\
0 \\
1.12 \\
1.5 \\
2.07 \\
2.27\end{array}$ & $\begin{array}{l}2 \\
0 \\
2.32 \\
2.32 \\
2.58 \\
2.81\end{array}$ & $\begin{array}{l}1.55 \\
0 \\
1.12 \\
0.88 \\
0.85 \\
0.88\end{array}$ & $\begin{array}{l}4 \\
1 \\
5 \\
5 \\
6 \\
7\end{array}$ \\
\hline 9 & $\begin{array}{r}10 / 85 \\
12 / 85 \\
1 / 86 \\
2 / 86 \\
3 / 86\end{array}$ & $\begin{array}{l}2.25 \\
1.15 \\
1.95 \\
2.07 \\
1.55\end{array}$ & $\begin{array}{l}2.81 \\
1.58 \\
3 \\
3.17 \\
3.32\end{array}$ & $\begin{array}{l}0.9 \\
1.15 \\
0.8 \\
0.25 \\
1.26\end{array}$ & $\begin{array}{r}7 \\
3 \\
4 \\
9 \\
10\end{array}$ \\
\hline 10 & $\begin{array}{r}10 / 85 \\
12 / 85 \\
1 / 86 \\
2 / 86 \\
3 / 86\end{array}$ & $\begin{array}{l}0.89 \\
1.79 \\
2.09 \\
2.35 \\
1.93\end{array}$ & $\begin{array}{l}3 \\
2 \\
2.32 \\
2.91 \\
3.32\end{array}$ & $\begin{array}{l}0.4 \\
1.04 \\
1.26 \\
0.64 \\
0.45\end{array}$ & $\begin{array}{r}0 \\
4 \\
5 \\
7 \\
10\end{array}$ \\
\hline 11 & $3 / 86$ & 2.53 & 3.46 & 0.34 & 11 \\
\hline
\end{tabular}

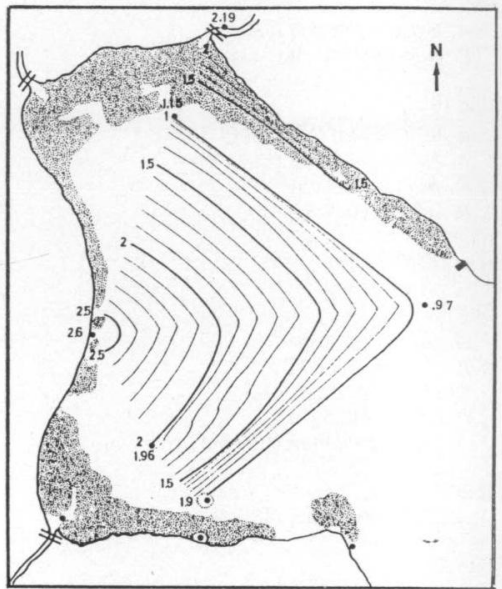

Fig. 5. Species diversity isolines of winter sampling.

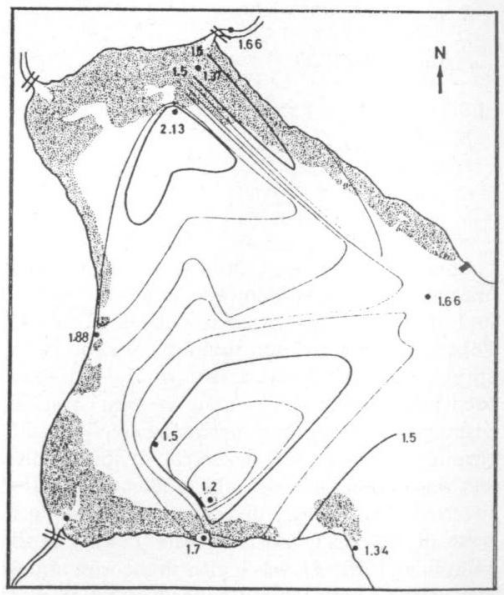

Fig. 6. Species diversity isolines of spring sampling. 


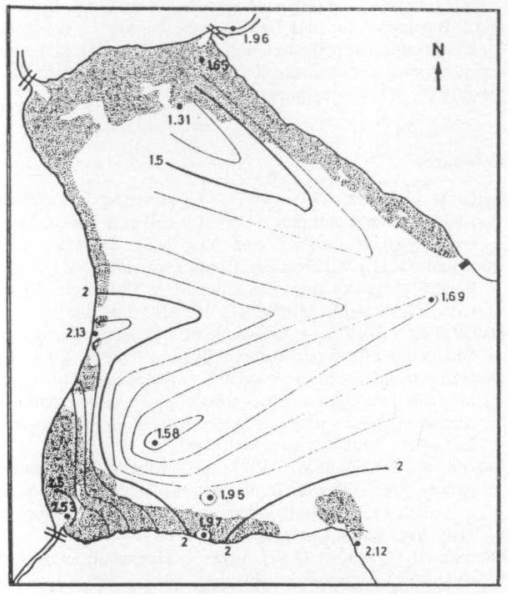

Fig. 7. Species diversity isolines of summer sampling.

Changes in fish populations are connected to habitat evolution (Gorman \& Karr 1978), reflected both in relative abundance changes and in their addition or replacement. However, opportunistic species present great tolerance to certain habitats (Larkin 1956). Some fish species in Chascomús lake could be considered opportunistic, while others are limited by some variable but are tolerant to others factors, and a third group are conditioned by intrinsic behaviour. The latter is defined in terms of presence, not abundance.

Unlike in Wisconsin lakes (Tonn \& Magnuson 1982), fish communities in this lake are not seasonally stable in the different habitats defined here (Table III, fig. 3). However, different abundancedefined groups or subsystems of macrophyte and fish species can be considered :

- Open water environments, predominantly associated to $P$. valenciennesi and $R$. m. limnoica, like sampling sites 5 and 7 .

- Off-shore with sparse bulrush, like sampling site 8 , associated with $P$. valenciennesi, $R$. m. limnoica, $A$. eigenmanniorum and $O$. jenynsi.
Table V. Mean species richness (X) and standard deviation (S) of sampling sites. (n : sample size).

\begin{tabular}{llll}
\hline SAMPLING SITES & $\bar{x}$ & 5 & $n$ \\
\hline 1 & 5.8 & 2.77 & 5 \\
2 & 3.66 & 2.00 & 3 \\
3 & 3.83 & 1.33 & 6 \\
5 & 4 & 1.63 & 4 \\
6 & 6.57 & 1.9 & 7 \\
7 & 4 & 1.55 & 6 \\
8 & 4.67 & 2.06 & 6 \\
9 & 6.5 & 2.74 & 6 \\
10 & 0.8 & 2.39 & 5 \\
11 & 11 & 0 & 1 \\
\hline
\end{tabular}

- Stream mouth with S. californicus, C. demersum marsh vegetation and mud substrate like sampling site 11 and 2, associated with $P$. gilberti, $P$. laticeps and $A$. eigenmanniorum.

- Littoral with mud substrate habitat and coast with $S$. californicus, $M$. quitense, $C$. demersum and mud substrate, like sampling site 9 , with predominance of $A$. eigenmannionum and $P$. laticeps.

- Littoral with caliche substrate and higher oxygen, with predominance of bulrush and vegetated species like $A$. eigenmanniorum and $P$. laticeps and plankton-feeding species like $R$. $m$. limnoica and $P$. valenciennesi, sampling sites 6 and 10 .

- Higher turbulence habitat, with abundant vegetation and shallow water, with occurrence of Ch. interruptus and occasionally C. decenmaculatus, J. lineata and C. paleatus, like sampling site 1.

During spring 1985 the increase in rainfall produced a drastic seasonal hydroperiod, provoking environmental changes by dilution waters, like the disappearance of $P$. striatus. 
The diversity varies according to environment and season. Gradients between sampling sites are sometimes significant boundaries, like bulrushes separating sites 1 and 11 from the lake. Both during winter and summer, diversity is higher at the mouth of the stream. The opposite occurs in spring. Bulrushes correspond to highly eutrophic areas with low diversity and species density in summer, due to shallowness, abundant vegetation, high temperature and low oxygen concentration. A higher fish diversity is expected in less eutrophic areas.

The higher diversity on the west coast may be due to macrophytes, mainly bulrush. According to Ringuelet (1975) most of the species in this lake were typical inhabitants of vegetated waters. This area, mainly the southwest, is protected from south wind by a headland (site 10 ).

A small, temporary stream of pluvial origin flows into site 6 , providing lower turbidity (less humic substances), higher transparency and lower temperature, which may determine higher species richness and occasionally higher diversity. Low spring diversity may be due to reproductive period and presence of alevines.

According to Margalef (1974), diversity differences on both sides of an asymetric interface are often evident and their isoentropic lines generally correspond to those of equal value of the gradient production/biomass or production/respiration. When the biotic diversity is under maximum diversity, the system is more exploitable. If the system is saturated, i.e. if all the niches are full, very little can be taken out of the system.

Therefore, out of the two subsystems related by an asymetric interface, the exploited subsystem will be the less saturated. Although a diversity gradient between sites 1 and 2 as well as between sites 11 and 7 shows higher saturation at the mouth of the stream (fig. 7), in no case does diversity get to the maximum (Table IV) so that any of the subsystems defined in this lake can export production to other communities.

\section{Acknowledgments}

This research is part of a thesis submitted to the Facultad de Ciencias Exactas, Fisicas y Naturales, Univerşidad Nacional de Córdoba (Argentina) in partial fulfilment of requirements for a Doctorate degree, under the direction of Professor L. R. Freyre, Facultad de Ciencias Naturales y Museo, Universidad Nacional de La Plata.
I am grateful to the following persons : R. Iriart, R. Escaray and J, Bustingorri for field assistance, N. Tur and C. Skorupka for identification of plant material, M. S. Rosenfeld for computing program assistance, and R. Menni, S. Gómez and A. Boltovskoy for valuable comments.

\section{References}

Barla (M. J.) \& Iriart (R.). 1987. - La presencia de Cyprinus carpio L. (Ostheichthyens, Cypriniformes) en la laguna Chascomús y su significado. Limnobios, 2 (9) : 685-686.

Conzonno (V.H.) \& Fernandez Cirelli (A.). 1987. - Soluble humic substances from the affluents of Chascomús Pond (Argentina). Arch. Hydrobiol., 102 (2) : 305-314.

Dangavs (N.V.). 1976. - Relevamiento batimétrico laguna de Chascomús. Convenio Estudio Riqueza lcticola, Tomo I.

Destefenis (S.) \& Freyre (L.R.). 1972. - Relaciones tróficas de los peces de la laguna Chascomús con un intento de referenciación ecológica y tratamiento bioestadístico del espectro trófico. Acta Zool. Lilloana $29: 17-53$.

Gascon (D.) \& Legget (W.). 1977. - Distribution, abundance and resource utilization of littoral zone fishes in response to a nutrient / production gradient in lake Memphremagog. $J$. Fish. Res, Board Can., 34 : 1105-1117.

Gorman (O.T.) \& Karr (J.R.). 1978. - Habitat structure and stream fish communities. Ecology, 59 (3) : 507-515.

Hernando Casal (J.A.) \& J. Muela (V.). 1980. - Clasificación cualitativa de diferentes áreas de la Marisma del Guadalquivir en relación con su ictiofauna. 1. Reunión Iberoaeri. Zool. Vert., La Rábida 1977 : $175-182$.

Hubalek (Z.). 1982. - Coefficients of association and similarity, based on binary (presence+absence) data : an evaluation. Biol. Rev., $57: 669-689$.

Hutchinson (G.E.). 1957, - A Treatrise on Limnology. Vol. I. John Wiley \& Sons, inc. New York, 1001 p.

Larkin (P.A.). 1956. - Interespecific competition and population control in freshwater fish. J. Fish. Res. Board Can., 13 (3) : 327-342.

Legendre (L.) \& Legendre (P.). 1979. - Ecologie Numérique. Masson. Paris. Tome II, 247 p.

Lowe-McConnell (R.H.). 1975. - Fish Communities in Troptcal Freshwaters. Longman, London and New York, 337 p.

Margalef (R.). 1974. - Ecologia. Omega. Barcelona, 951 p.

Margalef (R.). 1980. La Biósfera entre la Termodinámica y el Juego. Omega. Barcelona, $236 \mathrm{p}$.

Moreau (G.) \& Legendre (L.). 1979. - Relation entre habitat et peuplements de poissons : essai de définition d'une méthode numérique pour des rivières nordiques. Hydrobiologia 67 (1) : $81-87$.

Nédélec (C.). 1975. - Catalogue of Small-scale Fishing Gear. Fishery Industries Division. FAO. 191 p.

Pérez (L.E.). 1984. - Uso del hábitat por la comunidad de peces de un rio tropical asociado a un bosque. Estación Hidrobiológica de Guayana. Fundación La Salle de Ciencias Naturales, $10: 143-162$.

Pianka (E.R.). 1982. Ecologia Evolttiva. Omega. Barcelona, $365 \mathrm{p}$.

Pignalberi de Hassan (C.) \& Cordiviola de Yuan (E.). 1988. Fish population in the Paraguay river waters of the Formosa area, Argentina. Studies on Neotropical Fauna and Environment. 23 (3) : 165-175. 
Ringuelet (R.A.). 1962. - Ecología Acuótica Continental. Eudeba, Bs. As., $138 \mathrm{pp}$.

Ringuelet (R.A.). 1972. - Ecología y biocenologia del habitat lagunar o lago de tercer orden de la región Neotropical templada (Pampasia sudoriental de la Argentina). Physis., 31 (82) : 55-76.

Ringuelet (R.A.). 1975. - Zoogeografía y ecología de los peces de aguas continentales de la Argentina y consideraciones sobre las areas ictiológicas de América del Sur. Ecosur, 2 (3) : 1-122.
Savard (L.) \& Moreau (G.). 1982. - Etude des relations entre les communautés piscicoles et les differents habitats d'une rivière nordique : notions d'habitat proximal. Can. J. Zool. 60: 3344-3352.

Tonn (W.M.) \& Magnuson (J.J.). 1982. - Patterns in the species composition and richness of fish assemblages in northern Wisconsin lakes. Ecology 63 (4) : 1149.1166. 